\title{
ERRATUM TO: MAXIMUM LIKELIHOOD ESTIMATION OF A SOCIAL RELATIONS STRUCTURAL EQUATION MODEL
}

\author{
STEFFEN NESTLER(i) \\ UNIVERSITY OF MÜNSTER \\ OLIVER LUDTKE AND ALEXANDER ROBITZSCH \\ LEIBNIZ INSTITUTE FOR SCIENCE AND MATHEMATICS EDUCATION \\ CENTRE FOR INTERNATIONAL STUDENT ASSESSMENT
}

Erratum to: Psychometrika vol. 85, no. 4, 870-889

https://doi.org/10.1007/s11336-020-09728-z

The article MAXIMUM LIKELIHOOD ESTIMATION OF A SOCIAL RELATIONS STRUCTURAL EQUATION MODEL, written by Steffen Nestler, was originally published electronically on the publisher's internet portal on 22 January 2021 without open access. With the author(s)' decision to opt for Open Choice, the copyright of the article changed on 12 July 2021 to (C) The Author(s) 2021 and the article is forthwith distributed under a Creative Commons Attribution.

Funding Open Access funding enabled and organized by Projekt DEAL.

Open Access This article is licensed under a Creative Commons Attribution 4.0 International License, which permits use, sharing, adaptation, distribution and reproduction in any medium or format, as long as you give appropriate credit to the original author(s) and the source, provide a link to the Creative Commons licence, and indicate if changes were made. The images or other third party material in this article are included in the article's Creative Commons licence, unless indicated otherwise in a credit line to the material. If material is not included in the article's Creative Commons licence and your intended use is not permitted by statutory regulation or exceeds the permitted use, you will need to obtain permission directly from the copyright holder. To view a copy of this licence, visit http://creativecommons.org/licenses/by/4.0/.

Publisher's Note Springer Nature remains neutral with regard to jurisdictional claims in published maps and institutional affiliations.

The original article can be found online at https://doi.org/10.1007/s11336-020-09728-z.

Correspondence should be made to Steffen Nestler, Institut für Psychologie, University of Münster, Fliednerstr. 21, 48149 Münster, Germany. Email: steffen.nestler@uni-muenster.de 